\title{
Purification and molecular characterization of recombinant rat betacellulin
}

\section{A J Dunbar, I K Priebe, M P Sanderson ${ }^{1}$ and C Goddard ${ }^{1}$}

\author{
Cooperative Research Centre for Tissue Growth and Repair, CSIRO Health Sciences and Nutrition, \\ PO Box 10065 Adelaide BC, South Australia 5000, Australia \\ ${ }^{1}$ GroPep Limited, PO Box 10065, Adelaide BC, South Australia 5000, Australia
}

(Requests for offprints should be addressed to A J Dunbar; Email: andrew.dunbar@gropep.com.au)

\begin{abstract}
A method for the large scale expression and purification of rat betacellulin (BTC) from Escherichia coli has been developed using a cleavable fusion protein strategy. Insoluble fusion protein collected as inclusion bodies was dissolved in urea under reducing conditions, re-folded, and purified by gel filtration chromatography and $\mathrm{C}_{4}$ RP-HPLC. Authentic rat BTC was obtained after proteolytic cleavage of the fusion protein with Factor Xa.
\end{abstract}

Factor Xa cleaved an additional site within the BTC protein, generating a truncated isoform separable from full-length BTC by heparin-affinity chromatography. Recombinant rat BTC stimulated the proliferation of mouse Balb/c 3T3 fibroblasts and competed for binding to the ErbB1 receptor in a dose-dependent manner analogous to that of BTC purified from natural sources.

Fournal of Molecular Endocrinology (2001) 27, 239-247

\section{INTRODUCTION}

Betacellulin (BTC) belongs to a class of growth factors characterized by a six-cysteine consensus motif that forms three intramolecular disulphide bonds critical for binding to the ErbB receptor tyrosine kinase family (Dunbar \& Goddard 2000). Collectively, this group of proteins are referred to as the epidermal growth factor (EGF) family. Mammalian members of this family identified to date include EGF, amphiregulin, and transforming growth factor $-\alpha$ (TGF- $\alpha$ ), which bind specifically to ErbB1, and heparin-binding EGF (HB-EGF), epiregulin and BTC, which exhibit dual receptor specificity in that they bind both ErbB1 and ErbB4. The third group comprises the neuregulins (NRGs) which encompass the products of four genes (NRG1-NRG4). Members of this sub-family bind ErbB4 but not ErbB1, and can bind ErbB3 in the context of an ErbB2-ErbB3 heterodimer (Harari \& Yarden 2000). Recently, a new member of the EGF family has been described (Strachan et al. 2001). This molecule, termed epigen, has been shown to activate ErbB1. Characterization of the full ErbB receptor specificity of epigen, however, awaits further investigation. Binding and activation of the ErbB receptors by the EGF family results in the initiation and transmission of highly conserved signal transduction cascades (such as the mitogenactivated protein kinase and phosphatidyl inositol 3-kinase pathways), culminating in diverse cellular effects, including growth, differentiation, migration and survival.

BTC was initially purified and characterized from the conditioned medium of a mouse pancreatic $\beta$-cell carcinoma cell line (Shing et al. 1993) and subsequently has been identified and characterized in human (Sasada et al. 1993), bovine (Dunbar et al. 1999) and rat (Tada et al. 2000). Increased expression of BTC mRNA in the pancreas compared with other tissues, and an increasing number of in vitro studies with cultured cell lines have supported the hypothesis that BTC signaling through ErbB receptors plays an important part in islet growth and development in the pancreas. For example BTC, together with activin-A, can convert populations of AR42J rat pancreatic tumour cells into insulin-secreting cells (Mashima et al. 1996); BTC is required for the induction of insulin and glucokinase gene expression in PDX-1-expressing glucagonoma cells (Watada et al. 1996) and BTC is able to mediate the proliferation and differentiation of the rat insulinoma cell line, INS-1 (Huotari et al. 1998). Significantly, in these studies, neither EGF 
or TGF- $\alpha$ could mimic these effects. In addition BTC has been shown to exert a mitogenic effect on human undifferentiated pancreatic epithelial cells (Demeterco et al. 2000) and ductal epithelial cells derived from developing pancreatic buds of rat embryos (Sundaresan et al. 1998). Furthermore, immunohistochemical analysis has localized BTC to primitive duct cells in fetal pancreas and to some islet cell populations closely associated with insulin producing cells (Miyagawa et al. 1999, Tada et al. 1999). More recently, detailed analysis of ErbB1 deficient (-/-) mice has revealed that disruption of ErbB1 signaling leads to defects in pancreatic epithelial proliferation and an associated delay in $\beta$-cell development (Miettinen et al. 2000).

In all cases described above, the evidence linking a role for BTC signaling to pancreas development and function through ErbB1 and possibly ErbB4 is based almost solely on the use of cultured cell lines in vitro. Clearly, analysis of animal models in which the $B T C$ gene has been either selectively eliminated or overexpressed in the pancreas in vivo will be important, together with detailed investigation into the effects of short- and long-term infusion of BTC into animal disease models. Indeed, a recent study by Yamamoto et al. (2000) revealed that administration of recombinant human BTC significantly improved glucose tolerance in mice with diabetes induced by selective perfusion of alloxan. This effect was considered to be the result of promoting $\beta$-differentiation and regeneration from ductal or acinar cells, or both.

In this paper we report a method for the large-scale production and purification of authentic recombinant rat BTC from Escherichia coli and the biological analysis of the purified protein. The ability to produce rat BTC in high yield and purity will be particularly useful in examining the physiological effects of the administration of BTC to various rodent models of human disease (including diabetes). Furthermore, these animal studies can be performed without the complication of potential immunological 'interference' after reaction to a heterologous protein (i.e. human BTC), particularly as we have recently demonstrated that human BTC is highly immunogenic in the rabbit (Bastian et al. 2000).

\section{MATERIALS AND METHODS}

\section{Cell culture}

Balb/c 3T3 and IEC-6 cells were from the American Type Tissue Culture Collection (Manassas, VA, USA) and AG2804 human lung fibroblasts were kindly donated by Dr J M Gunn (Texas A and M
University, College Station, TX, USA). Both cell lines were maintained in Dulbecco's modified Eagle's medium (DMEM) supplemented with $60 \mathrm{mg} / \mathrm{ml}$ penicillin, $100 \mathrm{mg} / \mathrm{ml}$ streptomycin, $1 \mathrm{mg} / \mathrm{ml}$ fungizone and $10 \%(\mathrm{v} / \mathrm{v})$ fetal bovine serum (FBS), and propagated at $37^{\circ} \mathrm{C}$ in a humidified atmosphere of $5 \% \mathrm{CO}_{2}$.

\section{Cloning and expression}

The cDNA encoding the mature form of rat BTC $\left(\mathrm{Asp}^{32}-\mathrm{Tyr}^{111}\right.$ ) was generated by RT-PCR. Total RNA was isolated from $80-90 \%$ confluent rat IEC-6 cells (ATCC CRL-1592) and cDNA synthesized from $1 \mu \mathrm{g}$ total RNA using oligo d'T primer and Superscript II (Life Technologies, Melbourne, Australia). The subsequent cDNA was used as a template for PCR with oligonucleotide primers, 5' ATC TAG GTT AAC ATC GAA GGT CGT GAT GGG AAC ACG ACC AGA ACC 3' (single underline, HpaI restriction site; double underline, nucleotide sequence encoding the Ile-Glu-Gly-Arg Factor Xa recognition site) and 5' CTA GAT AAG CTT TCA TCA GTA AAA CAG GTC $\overline{\text { CAC }}$

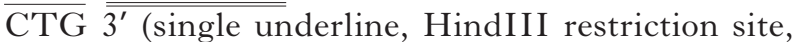
double underline stop codons). The resultant $282 \mathrm{bp}$ PCR product was purified, digested with $\mathrm{HpaI} /$ HindIII and cloned into HpaI/HindIIIdigested 46-amino acid porcine growth hormone (pGH(1-46)) expression vector (King et al. 1992) to generate pGH(1-46)-Ile-Glu-Gly-Arg-BTC (Fig. $1)$. This vector was subsequently transformed into $E$. coli JM101. Large scale IPTG-induced protein expression was performed in $4 \times 1$ litre fermenters (Applicon, Schiedam, The Netherlands).

\section{Fusion protein purification and re-folding}

After fermentation, cells were disrupted by homogenization, and insoluble inclusion bodies collected by centrifugation $\left(10000 \mathrm{~g}, 25 \mathrm{~min}, 4^{\circ} \mathrm{C}\right)$. Inclusion bodies were washed twice with $30 \mathrm{mM} \mathrm{NaCl}$, $10 \mathrm{mM} \mathrm{KH} \mathrm{KO}_{4}, 0.5 \mathrm{mM} \mathrm{ZnCl}$ and resuspended at $10 \%(\mathrm{w} / \mathrm{v})$ in $100 \mathrm{mM}$ Tris $(\mathrm{pH} 9 \cdot 0), 8 \mathrm{M}$ urea, $40 \mathrm{mM}$ glycine, $40 \mathrm{mM}$ dithiothreitol (DTT) and $0.5 \mathrm{mM} \mathrm{ZnCl} 2$ and stirred for $30 \mathrm{~min}$ at room temperature. Solubilized inclusion bodies were centrifuged (14000 r.p.m., $20 \mathrm{~min})$ to remove particulate matter and the supernatant was applied to a Cellufine GCL-1000 column $(5 \times 100 \mathrm{~cm})$ (Chisso Corp., Tokyo, Japan) equilibrated with $100 \mathrm{mM}$ Tris ( $\mathrm{pH} 9 \cdot 0$ ), $8 \mathrm{M}$ urea, $40 \mathrm{mM}$ glycine, $40 \mathrm{mM}$ DTT and $0.5 \mathrm{mM} \mathrm{ZnCl} \mathrm{Zn}_{2}$, at $2 \mathrm{ml} / \mathrm{min}$. Fractions containing fusion protein (pGH46-rat BTC) were pooled and subject to oxidative re-folding by diluting the mixture to a final protein 
concentration of $0.1 \mathrm{mg} / \mathrm{ml}$ in buffer containing $100 \mathrm{mM}$ Tris ( $\mathrm{pH} 9 \cdot 0$ ), $4 \mathrm{M}$ urea, $40 \mathrm{mM}$ glycine, $5 \mathrm{mM}$ EDTA, $0.4 \mathrm{mM}$ DTT and $1 \mathrm{mM}$ 2-hydroxyethylsulphoxide. After being stirred for $3 \mathrm{~h}$ at room temperature, the re-fold reaction was terminated by $\mathrm{pH}$ adjustment to $4 \cdot 0$ with trifluoracetic acid (TFA), filtered against a $1 \mu \mathrm{m}$ membrane to remove insoluble material and the mixture applied to a $\mathrm{C}_{4}$ Prep-Pak RP-HPLC column $(40 \mathrm{~mm} \times 100 \mathrm{~mm} ; 300 \AA, \quad 15 \mu \mathrm{m}$; MilliporeWaters, North Ryde, NSW, Australia) at $50 \mathrm{ml} /$ min. After extensive washing in $0.1 \%$ TFA the fusion protein was eluted with a gradient of $15-50 \%$ acetonitrile over $70 \mathrm{~min}$ (in the presence of $0.08 \%$ TFA) at a flow rate of $25 \mathrm{ml} / \mathrm{min}$. Fractions were collected and those containing pure pGH46-rat BTC fusion protein (as determined by SDS-PAGE) were pooled and lyophilized.

\section{Factor Xa cleavage and purification}

pGH46-rat BTC fusion protein was dissolved in a minimal volume of $10 \mathrm{mM} \mathrm{HCl}$ and resuspended in $50 \mathrm{mM}$ Tris chloride (pH 8.0), $100 \mathrm{mM} \mathrm{NaCl}$, $1 \mathrm{mM} \mathrm{CaCl}$ to give a final protein concentration of $0.05 \mathrm{mg} / \mathrm{ml}$. One hundred units of Factor Xa (Amersham-Pharmacia Biotech., Castle Hill, NSW, Australia) were then added per $20 \mathrm{mg}$ fusion protein and the reaction carried out for $20 \mathrm{~h}$ at room temperature before terminating by $\mathrm{pH}$ adjustment to 3.0 with $1.5 \%$ TFA. Authentic rat BTC was separated from the pGH46 fusion partner by RP-HPLC. The cleavage reaction was diluted 1:4 (v/v) with $0 \cdot 1 \%$ TFA and applied to a $\mathrm{C}_{4}$ RP-HPLC column $(2.5 \times 10 \mathrm{~cm}, 300 \AA$, Millipore-Waters $)$ at $20 \mathrm{ml} / \mathrm{min}$. The column was then washed with $0 \cdot 1 \%$ TFA and BTC eluted from the column with a linear gradient of $0-50 \%$ acetonitrile (in the presence of $0.08 \% \mathrm{TFA}$ ) at $25 \mathrm{ml} / \mathrm{min}$ over $80 \mathrm{~min}$. Fractions containing rat BTC were pooled and lyophilized. To separate full-length recombinant rat BTC from a shorter 'mis-cleaved' contaminant (see Results), the protein pool was resuspended in $50 \mathrm{mM}$ Tris chloride $(\mathrm{pH} 7 \cdot 5)$ and applied to a Progel-TSK Heparin-5PW column $(7.5 \mathrm{~mm} \times 7.5 \mathrm{~mm}$, Supelco, Castle Hill, NSW, Australia) attached to the HPLC at a flow rate of $0.5 \mathrm{ml} / \mathrm{min}$. The column was washed with $50 \mathrm{mM}$ Tris chloride $(\mathrm{pH} \mathrm{7.5)}$ and then eluted with a three-step gradient of $50 \mathrm{mM}$ Tris chloride $(\mathrm{pH} 7 \cdot 5) / 0 \cdot 2 \mathrm{M} \mathrm{NaCl}$ for $10 \mathrm{~min}$, followed by $50 \mathrm{mM}$ Tris chloride $(\mathrm{pH} 7 \cdot 5) / 0 \cdot 6 \mathrm{M}$ $\mathrm{NaCl}$ for $15 \mathrm{~min}$, followed by $50 \mathrm{mM}$ Tris chloride $(\mathrm{pH} 7 \cdot 5) / 0 \cdot 2 \mathrm{M} \mathrm{NaCl}$ for $10 \mathrm{~min}$. Fractions containing authentic full-length rat BTC were pooled, desalted and the purity of the final preparation analysed by microbore $\mathrm{C}_{4}$ RP-HPLC, electrospray ionization mass spectroscopy (Perkin-Elmer API 300, Shelton, CT, USA) and N-terminal sequence analysis (Hewlett-Packard G1000A, Palo Alto, CA, USA).

\section{Mitogenic and ErbB1 receptor binding assay}

Mitogenic activity of recombinant rat BTC (rrBTC) on Balb/c 3T3 fibroblasts was determined by colourimetric assay using methylene blue as previously described (Dunbar et al. 1999). The ability of $\mathrm{rrBTC}$ to bind ErbB1 specifically was determined by competitive displacement of ${ }^{125} \mathrm{I}$ recombinant human EGF (rhEGF) from ErbB1 receptors present on AG2804 human lung fibroblasts. Briefly, AG2804 cells were grown to $70-80 \%$ confluence in DMEM/10\% FBS in 24-well plates. The cells were washed twice with binding buffer (100 mM Hepes, (pH 7.6), $120 \mathrm{mM} \mathrm{NaCl}, 5 \mathrm{mM}$ $\mathrm{KCl}, 1 \cdot 2 \mathrm{mM} \mathrm{MgSO}_{4}, 8 \mathrm{mM}$ glucose, $0 \cdot 1 \% \mathrm{BSA}$ ) and then incubated with ${ }^{125} \mathrm{I}$-rhEGF (labeled with $\mathrm{Na}\left[{ }^{125} \mathrm{I}\right]$ using chloramine- $\mathrm{T}$ to a specific activity of approximately $20 \mu \mathrm{Ci} / \mu \mathrm{g}$ ) and increasing concentrations of unlabelled rrBTC $(0-44 \mathrm{nM})$ in binding buffer at $4{ }^{\circ} \mathrm{C}$ for $18 \mathrm{~h}$. Cells were then washed three times in Hanks's buffered salt solution and lysed with $1 \mathrm{ml} 0 \cdot 5 \mathrm{M} \mathrm{NaOH} / 0 \cdot 1 \%(\mathrm{v} / \mathrm{v})$ Triton X-100 for $30 \mathrm{~min}$. Radioactivities of cell lysates were then determined with a $\gamma$-counter (Wallac 1470). Nonspecific binding was determined by the addition of excess unlabelled rhEGF $(100 \mathrm{nM})$ and was typically about 5\% of total binding. Experimental data for both the mitogenesis assay and ErbB1 receptor binding assay were fitted to a logistic fourparameter dose-response model with variable slope (SigmaPlot v.4·0).

\section{ErbB-1 receptor tyrosine phosphorylation assay}

AG2804 cells were grown to confluence in $10 \mathrm{~cm}$ dishes and subsequently incubated for $12 \mathrm{~h}$ in serum-free medium. Cells were then stimulated with $10 \mathrm{nM}$ rrBTC for $10 \mathrm{~min}$ at room temperature, washed twice in PBS and then suspended in lysis buffer $(0.5 \mathrm{ml})(50 \mathrm{mM}$ Tris chloride $\mathrm{pH} 7 \cdot 4$, $150 \mathrm{mM} \mathrm{NaCl}, 1 \%$ deoxycholate, $1 \%$ Triton X-100, $0 \cdot 1 \%$ SDS, $5 \mathrm{mM}$ sodium orthovanadate, $10 \mathrm{mM}$ sodium fluoride, $1 \mathrm{mM}$ EGTA and complete protease inhibitors (Roche Biochemicals, Castle Hill, NSW, Australia). Cell lysates were cleared by centrifugation $\left(20 \mathrm{~min}, 15000 \mathrm{~g}\right.$ at $4{ }^{\circ} \mathrm{C}$ ) and ErbB1 immunoprecipitated by incubating the lysate with $1 \mu \mathrm{g}$ anti-ErbB1 (Upstate Biotech., New York, NY, USA) and protein-G sepharose (Roche Biochemicals) for $2 \mathrm{~h}$ at $4{ }^{\circ} \mathrm{C}$. Immune complexes were 


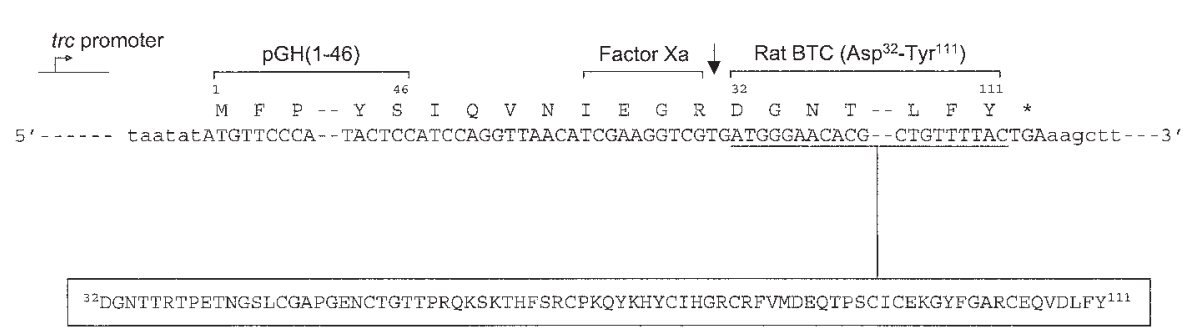

FIGURE 1. Description of the pGH(1-46)-rat BTC expression construct. The downward arrow indicates the Factor Xa cleavage point. Amino acid and nucleotide sequences of the various parts of the fusion protein are shown. The boxed amino acid sequence corresponds to the complete amino sequence of rat BTC $\left(\mathrm{Asp}^{32}-\mathrm{Tyr}^{111}\right)$. Note: amino acid numbering is with respect to the full 177 amino acids of the precursor rat BTC sequence. *Stop codon.

collected by centrifugation, washed three times in lysis buffer and heated $\left(3 \mathrm{~min}, 95^{\circ} \mathrm{C}\right)$ in SDSPAGE sample buffer. Proteins were separated on $6 \%$ SDS-PAGE gels and transferred to nitrocellulose filters (Hybond C, Amersham Pharmacia Biotech.). Blots were probed with antiphosphotyrosine monoclonal antibody (PY20, Santa Cruz Biotech., Santa Cruz, CA, USA) and then with HRP-conjugated sheep anti-mouse $\operatorname{IgG}$ (Silenus Laboratories, Boronia, Australia). HRPlabeled proteins were visualized using enhanced chemiluminescence (ECL) (Amersham Pharmacia Biotech.). To confirm equal loading, blots were stripped and re-probed with the anti-ErbB1 antibody and HRP-conjugated rabbit anti-sheep IgG (Zymed Laboratories Inc., San Francisco, CA, USA).

\section{Production of anti-rat BTC antibody}

Antibody production was approved by the Animal Ethics Committee of the Women's and Children's Hospital, Adelaide, South Australia and the procedure followed the Australian Code of Practice for the care and use of animals for scientific purposes. Briefly, three female semi-lop rabbits (obtained from the Institute of Medical and Vetinary Sciences, Gillies Plains, South Australia) were injected with $500 \mu \mathrm{g}$ of a 14-residue peptide $\left(\mathrm{G}^{50}\right.$ ENCTGTTPRQKSK $\left.{ }^{63}\right)$ conjugated to diptheria toxoid (Chiron Technologies, Melbourne, Victoria, Australia) in Freund's complete adjuvant, following standard procedures (Cooper \& Petterson 1999). After 6 weeks, animals were given a first booster injection of $100 \mu \mathrm{g}$ peptide in Freund's incomplete adjuvant; they received a similar, second boost, 4 weeks later. Blood samples were obtained 2 weeks after each booster injection for determination of antibody titre. Animals were killed 4 weeks after the second booster and blood collected by cardiac puncture. Rat BTC antisera was affinity-purified using a High Trap protein-G sepharose column (Amersham-Pharmacia Biotech.), following the manufacturer's instructions.

\section{RESULTS}

\section{Production and molecular characterization of rat BTC}

The mature form of rat BTC $\left(\mathrm{Asp}^{32}-\mathrm{Tyr}^{111}\right)$ was expressed as a recombinant fusion protein containing the first 46 amino-terminal amino acids of porcine growth hormone (pGH) (King et al. 1992). A proteolytic cleavage site (Ile-Glu-Gly-Arg) was engineered downstream of the $\mathrm{pGH}$ fusion partner to allow for 'release' of rat BTC after digestion with Factor Xa (Fig. 1).

Insoluble pGH46-rat BTC within inclusion bodies was dissolved in urea/DTT-containing buffer and partially purified by cellufine gel filtration chromatography to remove endogenous proteases. The solubilised fusion protein was then subject to oxidative re-folding in the presence of 2-hydroxyethyldisulphide. Fusion protein containing the correctly folded six-cysteine consensus EGF motif was then separated from mis-folded isomers by $\mathrm{C}_{4}$ RP-HPLC. pGH46-rat BTC fusion protein from this two-step procedure was considered to be essentially homogeneous as judged by analytical HPLC and SDS-PAGE (Fig. 2).

\section{Separation of the pGH fusion partner from authentic rat BTC}

Incubation of the fusion protein with Factor Xa for $20 \mathrm{~h}$ at $22^{\circ} \mathrm{C}$ generated a complex profile of protein peaks (P1-5) that were resolvable by $\mathrm{C}_{4}$ RP-HPLC (Fig. 3A, B). P3 was identified as containing rat 


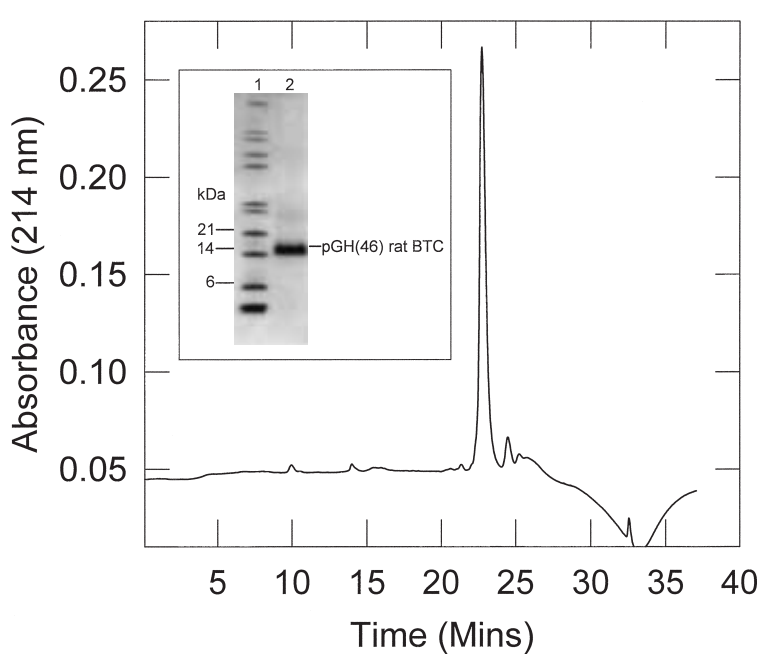

FIGURE 2. Analytical RP-HPLC analysis of purified pGH46-rat BTC fusion protein. An aliquot of the purified pGH46-rat BTC fusion protein preparation was analysed on a microbore $\mathrm{C}_{4}$ RP-HPLC column $(2 \cdot 1 \mathrm{~mm}$ $\times 100 \mathrm{~mm}$, Brownlee Laboratories, Santa Clara, CA, USA). Protein was eluted with an increasing gradient of acetonitrile to $80 \%$ in the presence of $0.08 \%$ TFA over 37 min. Inset: SDS-PAGE analysis of the purified preparation. Lane 1, molecular weight markers; lane 2, pGH46-rat BTC fusion protein.

BTC by monitoring mitogenic activity (data not shown). The identity and composition of the other peaks were not investigated. The purity of the recovered rat $\mathrm{BTC}(\mathrm{P} 3)$ was assessed by analytical RP-HPLC (Fig. 3C), SDS-PAGE and electrospray ionization mass spectrometry (Fig. 4A, B). A protein of $9036 \cdot 1 \pm 0.8 \mathrm{Da}$ corresponding to fulllength rat BTC (theoretical $M_{\mathrm{r}} 9034.2 \mathrm{Da}$ ) was identified. In addition however, a second protein species of $M_{\mathrm{r}} 5992 \cdot 0 \pm 0.4$ was present in approximately equivalent amounts. N-Terminal sequence analysis (five cycles) of the purified P3 preparation identified two protein sequences: Asp-Gly-AsnThr-Thr and Ser-Lys-Thr-His-Phe. Therefore, Factor Xa, in addition to cleaving pGH46-rat BTC fusion protein after Ile-Glu-Gly-Arg also cleaved an additional cryptic Factor Xa site within the BTC protein $\left({ }^{27}\right.$ Pro-Arg-Gln-Lys $\downarrow$ Ser-Lys-Thr ${ }^{33}$ ) (Fig. 4B). The theoretical molecular mass of the 'clipped' BTC isoform was predicted to be $5989 \cdot 6 \mathrm{Da}$ which is consistent with the observed molecular mass of $5992 \cdot 0 \pm 0 \cdot 4 \mathrm{Da}$. As expected, a polyclonal antibody raised against a synthetic peptide corresponding to the amino acid sequence Gly-Glu-Asn-Cys-ThrGly-Thr-Thr-Pro-Arg-Gln-Lys-Ser-Lys only recognized the full-length BTC isoform and not the clipped form (Fig. 4A).
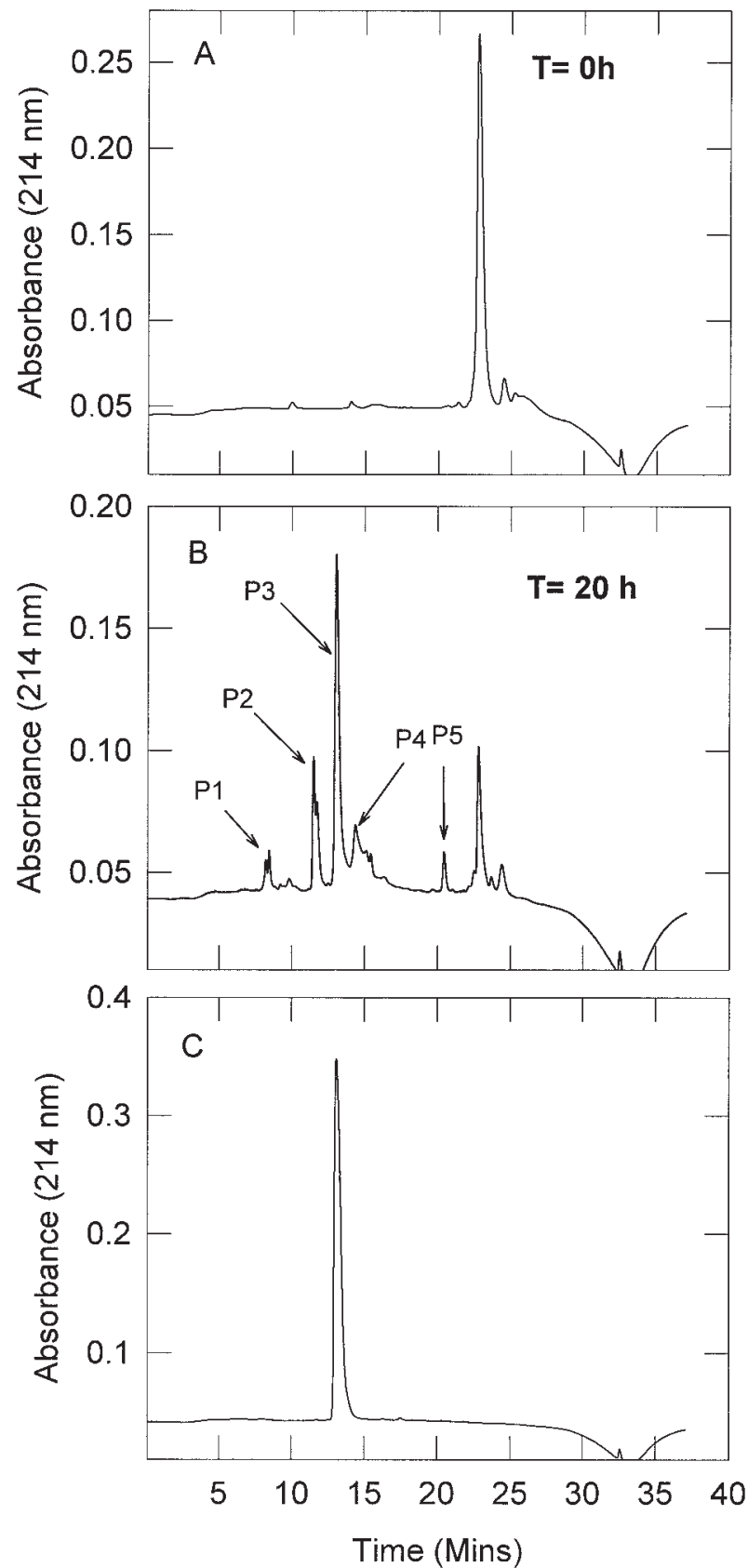

FIGURE 3. Analytical RP-HPLC of the pGH46-rat BTC fusion protein cleavage reaction. Pure pGH46rat BTC fusion protein was incubated for $20 \mathrm{~h}$ with Factor $\mathrm{Xa}$ at $22{ }^{\circ} \mathrm{C}$ and an aliquot of the reaction analysed by microbore $\mathrm{C}_{4}$ RP-HPLC as described in Fig. 2. (A) RP-HPLC analysis of the pGH46-rat BTC fusion protein at baseline $(\mathrm{T}=0 \mathrm{~h})$. (B) Analysis of an aliquot of the reaction after $20 \mathrm{~h}(\mathrm{~T}=20 \mathrm{~h})$. (C) Analysis of an aliquot of pooled fractions containing P3 after large-scale resolution of the factor $\mathrm{Xa}$ peptides. 
A
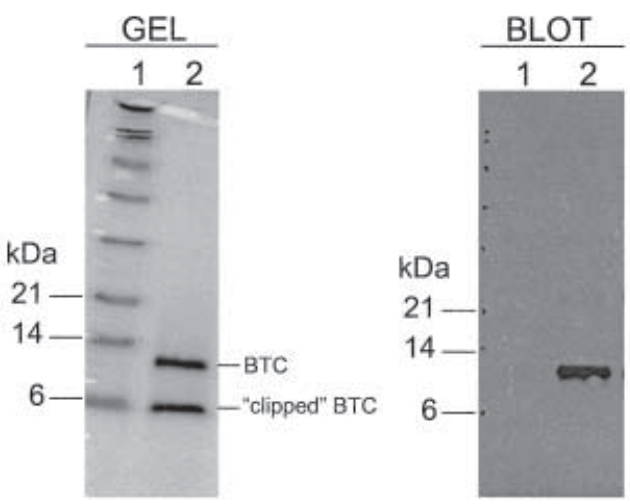

B

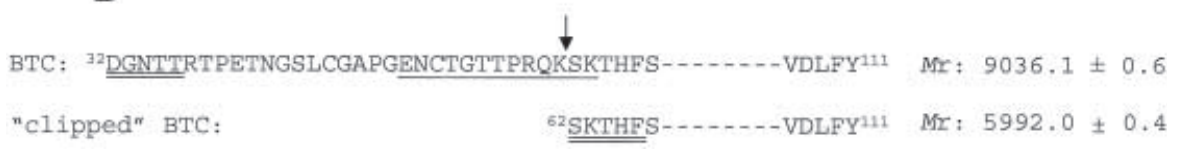

FIGURE 4. (A) SDS-PAGE and western blot analysis of the purified P3

preparation. An aliquot of the P3 preparation was resolved by SDS-PAGE and either stained with Coomassie blue (left panel) or immunoblotted and probed with a polyclonal anti-rat BTC antibody to the peptide Glu-Asn-Cys-Thr-Gly-

Thr-Thr-Pro-Arg-Gln-Lys (right panel). (B) N-terminal sequence analysis (five cycles) (double underline) and electrospray ionization mass spectrometry of the P3 preparation. Single underline indicates the amino acid sequence used to generate a polyclonal anti-rat BTC antibody. $\downarrow$ indicates the cryptic Factor Xa cleavage site within the BTC protein.

Heparin-affinity chromatography effectively separated the full-length and clipped BTC isoforms (Fig. 5A, B). Full-length BTC eluted slightly earlier than the clipped form $(0.32 \mathrm{M}$ and $0.4 \mathrm{M} \mathrm{NaCl}$ respectively). Fractions collected from the heparinaffinity column containing full-length rat BTC were pooled, desalted and analysed by analytical RPHPLC, electrospray ionization mass spectrometry and N-terminal sequence analysis. The purified peptide eluted as a single symmetrical peak (Fig. 5C) with a molecular weight of $9036 \mathrm{Da}$. $\mathrm{N}$-Terminal sequence analysis confirmed the presence of only a single protein sequence, corresponding to rat BTC.

\section{Biological activity of rrBTC}

rrBTC competed with ${ }^{125} \mathrm{I}$-rhEGF for binding to ErbB1 receptors present on AG2804 cells in a dose-dependent fashion; $50 \%$ inhibition of binding $\left(\mathrm{IC}_{50}\right)$ of ${ }^{125} \mathrm{I}$-rhEGF was observed at $0.68 \pm$ $0.05 \mathrm{nM}$ (mean \pm s.D.) (Fig. 6A). To determine whether binding to the extracellular domain of ErbB1 activated the receptor, AG2804 cells were incubated with or without rrBTC. After immunoprecipitation with an anti-ErbB1 antibody, tyrosine phosphorylation of the ErbB1 receptor was analysed by western blotting using anti-phosphotyrosine antibodies. rrBTC clearly induced ErbB1 phosphorylation compared with control (Fig. 6A, inset). Furthermore, binding of rrBTC to ErbB1 receptors also stimulated the proliferation of Balb/c 3T3 cells in a dose-dependent fashion (Fig. 6B).

\section{DISCUSSION}

Human BTC has previously been produced in $E$. coli as a recombinant protein encompassing the mature peptide $\left(\mathrm{Asp}^{32}-\mathrm{Tyr}^{111}\right)$. To initiate translation of this protein, a methionine residue was appended to the amino-terminus $\left(\mathrm{Asp}^{32}\right.$ ) (Seno et al. 1996). Here we have sought to produce, in large yields, a rat BTC of which the authenticity would not be compromised by the presence of additional amino acids at the amino-terminus. To do this, the mature form of rat BTC $\left(\mathrm{Asp}^{32}-\mathrm{Tyr}^{111}\right)$ was expressed in $E$. coli as a fusion protein in which a site-specific proteolytic cleavage site was engineered downstream of the fusion partner. This allowed for the generation of authentic BTC 


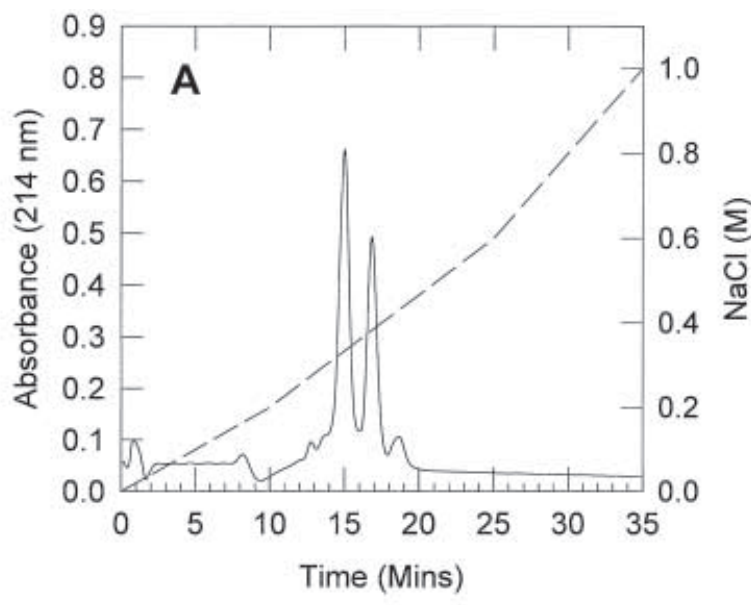

B
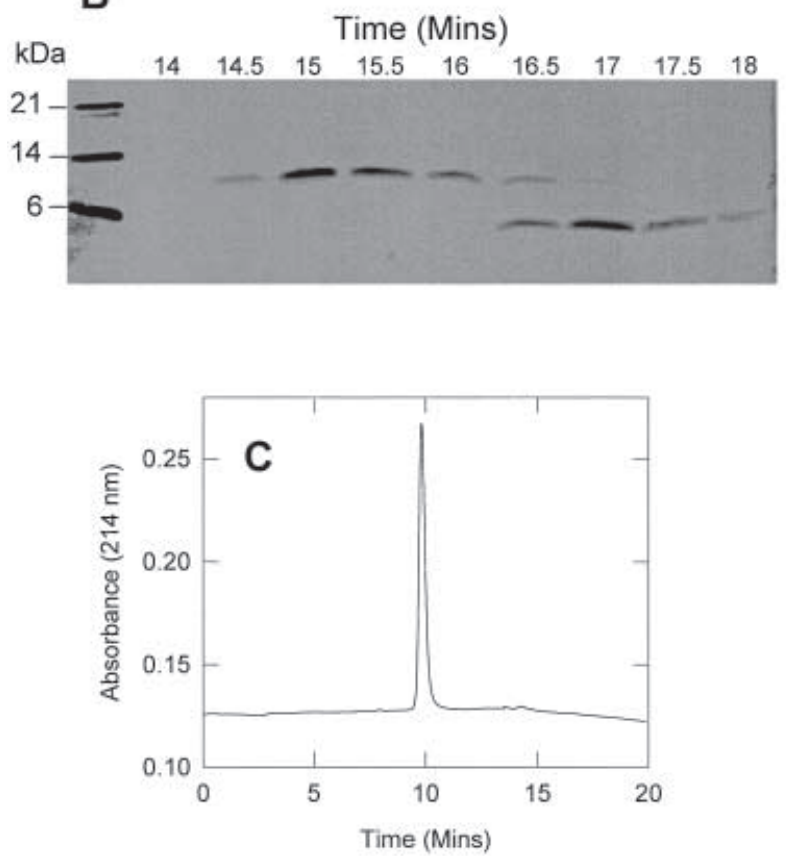

FIGURE 5. Heparin-affinity chromatography. The P3 preparation was further resolved on a Progel-TSK Heparin-5PW HPLC affinity column (A). Fractions were analysed by SDS-PAGE (B) and those containing pure rat BTC were pooled. Pure rat BTC ran as a single symmetrical peak when analysed by microbore $\mathrm{C}_{4}$ RP-HPLC with a gradient of $0-50 \%$ acetonitrile over $20 \min (\mathrm{C})$.

without the need to insert an amino-terminal methionine residue for translation initiation.

Like many other proteins that are overproduced in $E$. coli, pGH46-rat BTC fusion protein aggregated in the cell to form insoluble inclusion bodies. This insolubility made it possible to partially purify the protein from lysed cells by a simple low-speed

www.endocrinology.org
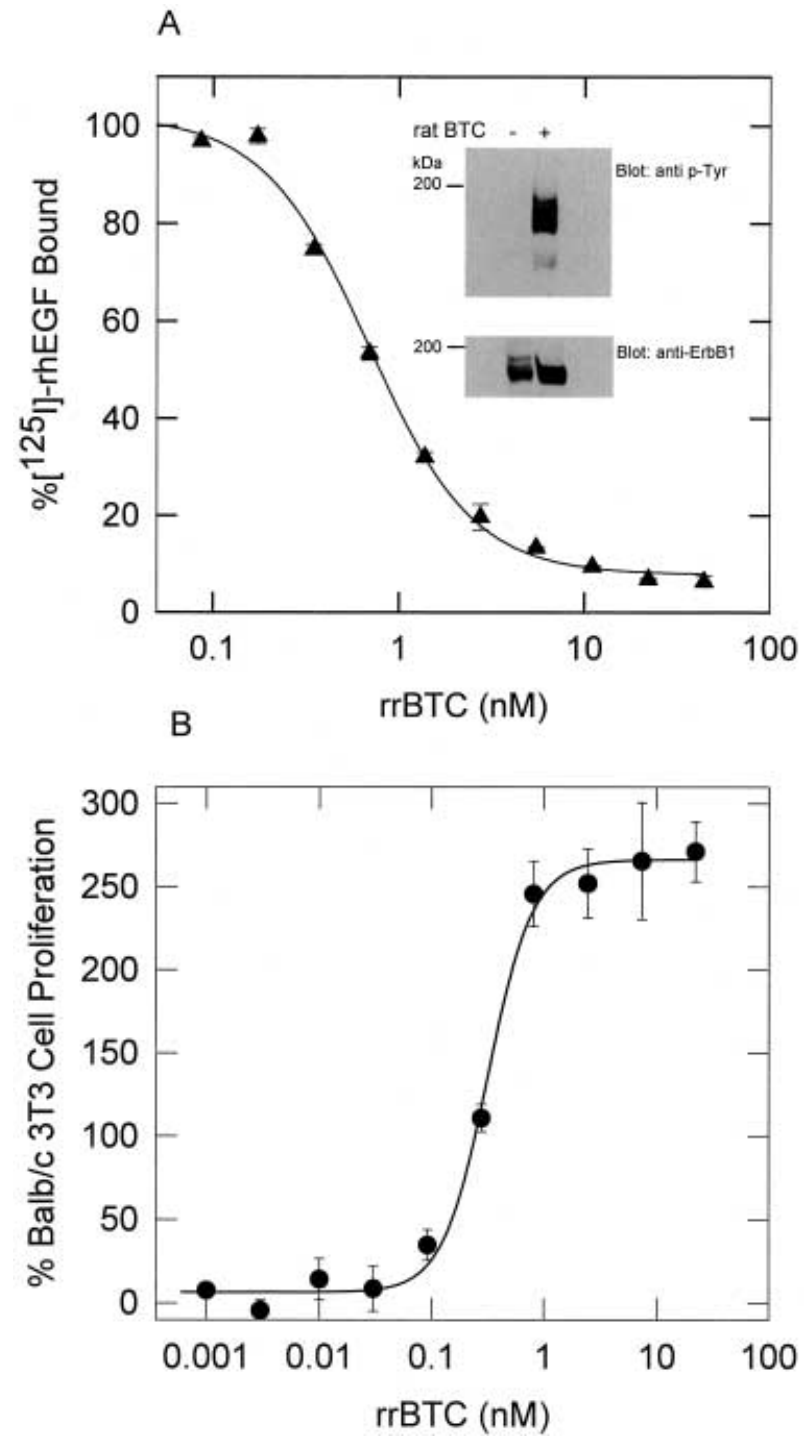

FIGURE 6. Biological activity of rrBTC. (A) Binding of rrBTC to ErbB1 receptors present on AG2804 cells.

${ }^{125}$ I-rhEGF was added to AG2804 cells with increasing amounts of rrBTC. Inset: ErbB1 receptor phosphorylation. AG2804 cells were treated with or without rrBTC and ErbB1 receptor phosphorylation examined by immunoprecipitation and western blotting with antiphosphotyrosine (p-Tyr) antibody. (B) Promotion of Balb/c 3T3 cell proliferation in the presence of rrBTC: cell proliferation is expressed as the \% increase in absorbance $(655 \mathrm{~nm})$ above control lacking growth factor. Data in (A) and (B) are means \pm s.D. for triplicate determinations and are fitted to a logistic four-parameter doseresponse model with variable slope (SigmaPlot v.4·0).

centrifugation in which the inclusion bodies segregated to the pellet phase. From 4 litres of induced culture, we typically obtained about 
$35 \mathrm{~g}$ (wet weight) of inclusion bodies, containing approximately $1 \mathrm{~g}$ of fusion protein. After dissolution of inclusion bodies and gel filtration to remove endogenous proteases, pGH46-rat BTC fusion protein was re-folded in the presence of 2-hydroxyethyldisulphide, and correctly folded protein containing the six-cysteine consensus EGF motif $\left(\mathrm{C}_{1}-\mathrm{C}_{3}, \mathrm{C}_{2}-\mathrm{C}_{4}\right.$ and $\left.\mathrm{C}_{5}-\mathrm{C}_{6}\right)$ separated from mis-folded 1-, 2- and 3-disulphide scrambled isomers by $\mathrm{C}_{4} \mathrm{RP}-\mathrm{HPLC}$.

The blood coagulation Factor Xa was then used to separate the $\mathrm{pGH}$ fusion partner from authentic rat BTC. In addition to cleaving the fusion protein at the canoconical tetrapeptide sequence Ile-Glu-GlyArg, Factor Xa also efficiently cleaved a nonspecific peptide sequence $\left({ }^{27}\right.$ Pro-Arg-Gln-Lys $\downarrow$ Ser-Lys-Thr ${ }^{33}$ ) within the N-terminal region of rat BTC. The non-specific Factor Xa cleavage event did not appear to be a secondary consequence of extended incubation, as a time course analysis demonstrated that the generation of both peptides occurred simultaneously (data not shown). Interestingly, recombinant human BTC produced in mouse A9 cells is sensitive to endogenous proteolytic cleavage in an identical position ( ${ }^{27}$ Thr-Gln-Ser-Lys $\downarrow$ ArgLys-Gly ${ }^{33}$ ), suggesting that this region within both human and rat BTC is overly susceptible to proteolytic cleavage (Watanabe et al. 1994).

Factor $\mathrm{Xa}$ is primarily specific for the Ile-GluGly-Arg recognition sequence, but it is also known to cleave additional sites. Only a few of these additional sites have been characterized, and they have little in common with the Ile-Glu-Gly-Arg sequence: for example, Cys-Asn-Gly-Arg $\downarrow$ Trp-Val (Nambiar et al. 1987), Ser-Leu-Ser-Arg $\downarrow$ Met-Thr (Quinlan et al. 1989), and Ala-Leu-Ala-Arg $\downarrow$ LysTyr (Nagai \& Thøgresen 1987). In some cases, where cleavage occurs immediately after lysine residues, as is the case here, reversible acylation by incubation with 3,4,5,6-tetrahydrophthalic anhydride is effective in blocking non-specific cleavage (Wearne 1990).

To separate full-length rat BTC from the clipped shorter form, we initially used RP-HPLC. However, even using very shallow gradients we were unable to achieve suitable separation of the two forms (data not shown). In contrast, heparin-affinity chromatography effectively separated the two forms (Fig. 5A, B). Full-length rat BTC eluted as a single peak from an analytical $\mathrm{C}_{4}$ RP-HPLC and was shown to be greater than $99 \%$ pure as judged by electrospray ionization mass spectrometry and $\mathrm{N}$-terminal sequence analysis. Using this procedure we were typically able to generate approximately $10-15 \mathrm{mg}$ pure rat BTC from 4 litres of starting culture.

\section{Biological activity of rrBTC}

The biological activity of the rrBTC preparation was evaluated by both ErbB1 receptor binding and phosphorylation, and mitogenic stimulation of mouse fibroblasts. Recombinant rat BTC competed with $\left[{ }^{125} \mathrm{I}\right]$-rhEGF for binding to ErbB1 receptors present on AG2804 cells in a dose-dependent fashion; $50 \%$ inhibition of binding $\left(\mathrm{IC}_{50}\right)$ of ${ }^{125} \mathrm{I}-\mathrm{rhEGF}$ was observed at $0.68 \pm 0.05 \mathrm{nM}$, consistent with the findings of previous studies examining human BTC binding to $\mathrm{CHO}$ cells expressing ErbB1 $\left(\mathrm{IC}_{50}=1 \mathrm{nM}\right.$; Pinkas-Kramarski et al. 1998). Binding of rrBTC to ErbB1 also induced receptor phosphorylation in AG2804 cells and stimulated proliferation of Balb/c 3T3 cells in a dose-dependent fashion (Fig. 6B). Interestingly, the clipped BTC also stimulated the proliferation of Balb/c 3T3 cells with a similar dose-dependency (data not shown), confirming previous reports that the amino-terminal 30 amino acids are dispensable for ErbB1 receptor binding and activation (Watanabe et al. 1994).

The expression system that we describe provides an efficient and consistent means of producing highly purified and biologically active full-length recombinant rat BTC. Authentic rat BTC will be useful in examining the effect(s) of the administration of this growth factor on various tissues (such as the pancreas) in normal rodents and various rodent models of human disease.

\section{ACKNOWLEDGEMENTS}

We thank Sam Randles for technical assistance, Jelle Lahnstein of the SRC for Basic and Applied Plant Molecular Biology for N-terminal sequence analysis and Yoji Hayasaka (The Australian Wine Research Institute) for electrospray ionization mass spectrometry. The Australian Federal Government Cooperative Research Centres Programme supported this work.

\section{REFERENCES}

Bastian SEP, Dunbar AJ, Priebe IK, Owens PC \& Goddard C 2000 Measurement of betacellulin levels in bovine serum, colostrums and milk. Fournal of Endocrinology 168 203-212.

Cooper HM \& Petterson Y 1999 Production of polyclonal antisera. In Current Protocols in Molecular Biology, vol I, pp $16 \cdot 2 \cdot 1-16 \cdot 2 \cdot 5$. Eds JS Bonifacino, M Dasso, JB Harford, J Lippincott-Schwatrz \& KM Yamada. New York: John Wiley.

Demeterco C, Beattie GM, Dib SA, Lopez AD \& Hayek A $2000 \mathrm{~A}$ role for activin A and betacellulin in human fetal pancreatic cell differentiation and growth. Fournal of Clinical Endocrinology and Metabolism 85 3892-3987. 
Dunbar AJ \& Goddard C 2000 Structure-function and biological role of betacellulin. International Fournal of Biochemistry and Molecular Biology 32 805-815.

Dunbar AJ, Priebe I K, Belford DA \& Goddard C 1999 Identification of betacellulin as a major peptide growth factor in milk: purification, characterization and molecular cloning of bovine betacellulin. Biochemical Fournal 344 713-721.

Harari D \& Yarden Y 2000 Molecular mechanisms underlying ErbB2/HER2 action in breast cancer. Oncogene 19 6102-6114.

Huotari M-A, Palgi J \& Otonkoski T 1998 Growth factormediated proliferation and differentiation of insulinproducing INS-1 and RINm5F cells: identification of betacellulin as a novel $\beta$-cell mitogen. Endocrinology 139 1494-1499.

King R, Wells JRE, Krieg P, Snoswell M, Brazier J, Bagley CJ, Wallace JC, Ballard FJ, Ross M \& Francis GL 1992 Production and characterization of recombinant insulin-like growth factor-1 (IGF-1) and potent analogues of IGF-1, with Gly or Arg substituted for $\mathrm{Glu}^{3}$, following their expression in Escherichia coli as fusion proteins. Fournal of Molecular Endocrinology 8 29-41.

Mashima H, Ohnishi H, Wakabayashi K, Mine T, Miyagawa J, Hanafusa T, Seno M, Yamada H \& Kojima I 1996 Betacellulin and activin A coordinately convert amylasesecreting pancreatic AR42J cells into insulin-secreting cells. Fournal of Clinical Investigation 97 1647-1654.

Miettinen PJ, Huotari M, Koivisto T, Ustinov J, Palgi J, Rasilainen S, Lehtonen E, Keski-Oja J \& Otonkoski T 2000 Impaired migration and delayed differentiation of pancreatic islet cells in mice lacking EGF-receptors. Development 127 $2617-2627$.

Miyagawa J-I, Hanafusa T, Sasada R, Yamamoto K, Igarashi K, Yamamori K, Seno M, Tada H, Nammo T, Li M, Yamagata K, Nakajima H, Namba M, Kuwajima M \& Matzuzawa Y 1999 Immunohistochemical localization of betacellulin, a new member of the EGF family, in normal human pancreas and islet tumor cells. Endocrine fournal 46 $755-764$.

Nagai K \& Thøgresen HC 1987 Synthesis and sequencespecific proteolysis of hybrid proteins produced in Escherichia coli. Methods in Enzymology 153 461-481.

Nambiar KP, Stackhouse J, Presnell SR \& Benner SA 1987 Expression of bovine pancreatic ribonuclease A in Escherichia coli. European Fournal of Biochemistry 16 67-71.

Pinkas-Kramarski R, Lenerink AEG, Bacus SS, Lyass L, van de Poll MLM, Klapper LN, Tzahar E, Sela M, van Zoelen EJJ \& Yarden Y 1998 The oncogenic ErbB-2/ErbB-3 heterodimer is a surrogate receptor of the epidermal growth factor and betacellulin. Oncogene 16 1249-1258.

Quinlan RA, Moir RD \& Stewart M 1989 Expression in Escherichia coli of fragments of glial fibrillary acidic protein: characterization, assembly properties and paracrystal formation. Fournal of Cell Science 93 71-83.
Sasada R, Ono Y, Taniyama Y, Shing Y, Folkman J \& lgarashi K 1993 Cloning and expression of cDNA encoding human betacellulin, a new member of the EGF family. Biochemical and Biophysical Research Communications 190 1173-1179.

Seno M, Tada H, Kosaka M, Sasada R, Igarashi K, Shing Y, Folkman J, Ueda M \& Yamada H 1996 Human betacellulin, a member of the EGF family dominantly expressed in pancreas and small intestine, is fully active in a monomeric form. Growth Factors 13 181-191.

Shing Y, Christafori G, Hanahan D, Ono Y, Sasada R, Igarashi K, Folkman J 1993 Betacellulin: a mitogen from pancreatic beta cell tumors. Science 259 1604-1607.

Strachan L, Murison JG, Prestidge RL, Sleeman MA, Watson JD \& Kumble KD 2001 Cloning and biological activity of epigen, a novel member of the EGF superfamily. Fournal of Biological Chemistry 276 18265-18271.

Sundaresan S, Roberts PE, King KL, Sliwkowski MX \& Mather JP 1998 Biological response to ErbB ligands in nontransformed cell lines correlates with a specific pattern of receptor expression. Endocrinology 139 4756-4764.

Tada H, Sasada R, Kawaguchi Y, Kojima I, Gullick WJ, Salomon DS, Igarashi K, Seno M \& Yamada H 1999 Processing and juxtacrine activity of membraneanchored betacellulin. Fournal of Cellular Biochemistry 72 423-434.

Tada H, Seno M, Yamada H, Sasada R \& Igarashi K 2000 Molecular cloning and expression of rat betacellulin. Biochimica et Biophysica Acta 1492 285-288.

Watada H, Kajimoto Y, Myagawa J, Hanafusa T, Hamaguchi K, Matsuoka TA, Yamamoto K, Matsuzawa Y, Kawamori R \& Yamasaki Y $1996 \mathrm{Pdx}-1$ induces insulin and glucokinase expressions in $\alpha$-TC 1 clone 6 cells in the presence of betacellulin. Diabetes 45 1826-1831.

Watanabe T, Shintani A, Nakata M, Shing Y, Folkman J, lgarashi K \& Sasada R 1994 Recombinant human betacellulin. Molecular structure, biological activities, and receptor interaction. Fournal of Biological Chemistry 269 9966-9973.

Wearne SJ 1990 Factor Xa cleavage of fusion proteins. Elimination of non-specific cleavage by reversible acylation. FEBS Letters 26323026.

Yamamoto K, Miyagawa J-I, Waguri M, Sasada R, Igarashi K, Li M, Nammo T, Moriwaki M, Imagawa A, Yamagata K, Nakajima H, Namba M, Tochino Y, Hanafusa T \& Matsuzawa Y 2000 Recombinant human betacellulin promotes the neogenesis of $\beta$-cells and ameliorates glucose intolerance in mice with diabetes induced by selective alloxan perfusion. Diabetes 49 2021-2027.

RECEIVED 20 March 2001

ACCEPTED 21 June 2001 